\title{
PENGARUH LAYANAN PEMBAYARAN PAJAK ONLINE PADA PT POS INDONESIA (PERSERO) CABANG MATARAM TERHADAP PENINGKATAN JUMLAH MASYARAKAT SADAR PAJAK
}

\author{
Siti Fatimah \\ Fakultas Ekonomi dan Bisnis Universitas Mataram \\ sitifatimah@unram.ac.id \\ Yudi Sukma \\ Fakultas Ekonomi dan Bisnis Universitas Mataram \\ yudisukma1105@gmail.com
}

\begin{abstract}
ABSTRAK
Pajak merupakan salah satu sumber penerimaan negara, dan memiliki kontribusi yang cukup tinggi di dalamnya. Bagi Indonesia, penerimaan pajak sangat sangat besar perannya dalam mengamankan anggaran negara dalam APBN / APBD setiap tahunnya, struktur penerimaan negara dalam APBN menempatkan penerimaan pajak sebagai pos penerimaan terbesar. Pajak di Indonesia memainkan peran penting dalam mengurangi defisit anggaran negara dan meningkatkan pembiayaan negara. Oleh karena itu, kebijakan pajak memiliki peran penting dalam pembangunan nasional. Hal ini lah yang menjadi alasan penulis untuk menggambil judul Pengaruh Layanan Pembayaran Pajak Online Pada PT. Pos Indonesia (Persero) Cabang Mataram Terhadap Peningkatan Jumlah Masyarakat Sadar Pajak.

Tujuannya untuk dapat mengetahui pengaruh penerapan program pajak online pada PT. Pos Indonesia (persero) cabang mataram terhadap kepatuhan wajib pajak dan untuk dapat mengetahui pemahaman internet dapat memoderenisasi hubungan antara penerapan program pajak online pada PT. Pos Indonesia (persero) cabang mataram dengan kepatuhan wajib pajak masyarakat.

Pengaruh layanan pembayaran pajak online pada PT. Pos Indonesia (persero) mataram terhadap peningkatan jumlah sadar pajak sesuai dengan peraturan menteri keuanngan republik Indonesia Nomor 32/PMK.05/2014 tentang sistem penerimaan negara secara elektronik telah berjalan dengan sangat baik, dimana Pt. Pos Indonesia memberi kemudahan dan kelancara pelaksanaan pembayaran pajak online bagi wajib pajak dalam melaksanakan pembayaran pajak. Dalam melaksanakan pembayaran pajak di kantor pos dengan menunjukkan kode billing kepada petugas loket pos, menyerahkan data data wajib pajak yang lengkap, menyetorkan uang sesuai jumlah yang sudah ditentukan, kemudian wajib pajak menerima resi pembayaran pajak sebagai bukti penerimaan negara.

Kata Kunci: Pajak Online, Masyarakat Pajak online
\end{abstract}

\section{PENDAHULUAN}

Kantor Pos adalah bagian dari lembaga pemerintah yang memfasilitasi sarana komunikasi bagi masyarakat. Bahkan lembaga ini sudah eksis sejak zaman Belanda. Pada awal berdiriya kartor pos, lembaga ini telah melayani pengiriman pesan berupa surat serta pengiriman uang. Dengan perkembangan teknologi yang sekarang, kantor pos mengembangkan fungsi menjadi lebih luas lagi, seperti menerima western union, pembayaran listrik, telepon dan lain-lain.

Dampak perkembangan teknologi, seperti adanya mesin fax, telepon, hp, dan internet membuat penyampaian pesan begitu mudah dan praktis. Kemajuan teknologi berdampak besar bagi masyarakat Indonesia pada khususnya dan berpengaruh pada 
perubahan yang saat ini lebih menyukai komunikasi langsung seperti menggunakan gadget dan alat komunikasi elektronik yang lain. Sebelum teknologi semua ini muncul, kantor pos adalah kantor yang sangat penting dan berjasa karena semua komunikasi hanya bisa melalui surat-menyurat. Banyaknya alternatif lain seperti yang dimaksud membuat fungsi kantor pos tergeser dalam hal pengiriman pesan, sehingga saat ini fungsi kantor pos lebih kepada bekerjasama dengan perusahaan, instansi maupun perguruan tinggi.

Kantor pos saat ini tidak hanya difungsikan sebagai jasa atau sarana pengiriman barang saja, dengan berjalannya waktu kantor pos juga membantu pemerintah dalam memberikan kemudahan bagi masyarakat untuk membayar pajak yang dimana masayarakat tidak harus datang ke instansi pajak secara langsung dengan program yang dimiliki oleh kantor pos yaitu pajak online.

Pajak online merupakan sistem elektronik yang disediakan oleh Dirjen Pajak atau pihak lain yang bekerja sama dengan pihak Dirjen Pajak. Tujuannya untuk mengadakan pelayanan dan transaksi elektronik terkait perpajakan. Keputusan terkait lapor pajak online ditulis dalam surat Edaran Dirjen Pajak Nomor SE-42/PJ/2017.

Tujuan utama program ini dijalankan untuk membantu pemerintah dalam menyadarkan masyarakat patuh wajib pajak dengan memberikan kemudahan dalam melakukan pembayaran pajak secara online tanpa harus membayar langsung ke Instansi Pajak.

Penerimaan pajak di Indonesia tergolong rendah. Salah satu penyebabnya dikarenakan tingkat kepatuhan wajib pajak yang semakin menurun. Penelitian tentang wajib pajak telah banyak dilakukan. Menurut Pratama (2012) wajib pajak yang ditetapkan oleh Direktur Jendral Pajak sebagai wajib pajak yang memenuhi kriteria tertentu yang dapat diberikan pengembalian pendahuluan kelebihan pembayaran pajak. Menurut Suryadi (2006) kepatuhan wajib pajak dibentuk oleh dimensi pemeriksaan pajak, penegakan hukum dan konpensasi pajak. Tujuan pemeriksaan adalah untuk menguji kepatuhan wajib pajak dalam melaksanakan perpajakan. Kepatuhan wajib pajak memenuhi kewajiban perpajakan meningkatan penerimaan negara dan pada gilirannya akan meningkatkan besarnya rasio pajak (Nurmantu, 2007).

Terkait pembayaran pajak online elektronik, kita mungkin pernah dengar atau merasa ini bukan hal yang baru. Karena beberapa saat lalu, pajak memang sudah dapat dibayar secara elektronik atau via Anjungan Tunai Mandiri (ATM). Sistem pembayaran ini memang sudah ada sejak tahun 2013, yang biasa kita kenal sebagai layanan id-billing dari Dirjen Pajak.

Sistem id-billing ini masih sangat terbatas, pembayaran yang dapat dilakukan dengan sistem ini hanya pembayaran pajak penghasilan. Diawal kemunculannya, idbilling juga hanyya dapat dilakukan dibank-bank tertentu saja. Namun seiring berjalannya waktu, pemerintah mencoba mengembangkan dengan mengeluarkan SSE Pajak versi 2 dan SSE Pajak versi 3.

Setelah pengadaan sistem id-billing, Dirjen Pajak mengeluarkan sistem pembayaran pajak yang disebut e-filling pajak. Sistem ini mengembangkan aplikasi dan pemberitahuan terkait wajib pajak di website Dirjen Pajak. Para wajib pajak nantinya bisa mengisi formulir pembayaran secara online disitus Dirjen Pajak.

Setelah pengadaan sistem id-billing dan e-filling pajak ini, pemerintah pun mengintegerasikan kedua sistem itu. Lebih tepatnya setelah Modul Penerimaan Negara Generasi Dua diluncurkan. Perintegrasian kedua sistem tersebut membuat Dirjen Pajak meluncurkan DJP Online. (www.jojonomic.com). Hal ini lah yang menjadi alasan penulis untuk menggambil judul "Pengaruh Layanan Pembayaran Pajak Online Pada PT. Pos Indonesia (Persero) Cabang Mataram Terhadap Peningkatan Jumlah Masyarakat Sadar Pajak". 


\section{Tujuan}

1. Untuk dapat mengetahui pengaruh penerapan program pajak online pada PT. Pos Indonesia (persero) cabang mataram terhadap kepatuhan wajib pajak.

2. Untuk dapat mengetahui pemahaman internet dapat memoderenisasi hubungan antara penerapan program pajak online pada PT. Pos Indonesia (persero) cabang mataram dengan kepatuhan wajib pajak masyarakat

\section{TELAAH LITERATUR DAN PENGEMBANGAN HIPOTESIS}

\section{Pengertian Pajak}

Beberapa pengertian pajak adalah sebagai berikut:

1) Menurut Prof. Dr. Rochmat Soemitro, S.H.

Pajak adalah iuran rakyat kepada kas negara berdasarkan undang-undang (yang dapat dipaksakan) dengan tidak mendapat jasa timbal balik (kontraprestasi) yang langsung dapat ditunjukkan dan yang digunakan untuk membayar pengeluaran umum.

Definisi tersebut kemudian disempurnakan pada edisi buku menjadi Pajak adalah peralihan kekayaan dari pihak rakyat kepada kas negara untuk membiayai pengeluaran rutin dan "surplus"-nya digunakan untuk public saving yang merupakan sumber utama untuk membiayai public investment. (Siti Resmi, 2017:1)

2) Menurut S. I. Djajadiningrat (dalam Siti Resmi, 2017 : 1 ) : "Pajak sebagai suatu kewajiban menyerahkan sebagian dari kekayaan dari kekayaan ke kas Negara yang disebabkan suatu keadaan, kejadian, dan perbuatan yang memberikan kedudukan tertentu, tetapi bukan sebagai hukuman, menurut peraturan yang detetapkan pemerintah serta dapat dipaksakan, tetapi tidak ada jasa timbal balik dari Negara secara langsung untuk memelihara kesejahteraan rakyat secara umum".

3) Menurut Undang-Undang Nomor 28 Tahun 2007 tentang Ketentuan Umum dan Tata Cara Perpajakan

Pajak adalah kontribusi wajib kepada negara yang terutang oleh orang pribadi atau badan yang bersifat memaksa berdasarkan undang-undang, dengan tidak mendapatkan imbalan secara langsung dan digunakan untuk keperluan negara bagi sebesar-besarnya kemakmuran rakyat. Dari beberapa definisi tersebut dapat ditarik kesimpulan bahwa ciri-ciri yang melekat pada definisi pajak adalah:

a. Pajak dipungut berdasarkan atau dengan kekuatan undang-undang serta aturan pelaksanaannya.

b. Dalam pembayaran pajak tidak dapat ditunjukkan adanya kontraprestasi individual oleh pemerintah.

c. Pajak dipungut oleh negara, baik pemerintah pusat maupun pemerintah daerah.

d. Pajak diperuntukkan bagi pengeluaran-pengeluaran pemerintah, yang bila dari pemasukannya masih terdapat surplus, digunakan untuk membiayai public investment. (Siti Resmi, 2017:18)

\section{Wajib pajak}

Menurut pasal 1 ayat 2 Undang-Undang Nomor 16 Tahun 2009 tentang KUP, waib pajak adalah orang pribadi atau badan (subjek pajak)meliputi membayar pajak, pemotongan pajak dan pemungutan pajak yang mempunyai hak dan kewajiban erpajakan sesuai dengan ketentuan peraturan Undang-Undang perpajaka

Setiap warga negara mempunyai kewajiban perpajakan dimulai sejak memenuhi persyaratan subyektif dan obyektif. Setiap Wajib Pajak yang telah memenuhi persyaratan subjektif dan objektif wajib memiliki Nomor Pokok Wajib Pajak (NPWP). NPWP adalah nomor pajak yang diberikan kepada Wajib Pajak sebagai sarana 
dalam administrasi perpajakan, yang digunakan sebagai tanda pengenal diri atau identitas Wajib Pajak untuk mempermudah dalam melaksanakan hak dan kewajiban perpajakannya. Setiap hal yang berhubungan dengan dokumen perpajakan, Wajib Pajak diwajibkan untuk mencantumkan NPWP yang dimilikinya (Nugroho, 2012).

Penelitian ini berkaitan dengan Wajib Pajak Orang Pribadi (WP OP). WP OP adalah orang pribadi yang memenuhi persyaratan subjektif dan objektif sesuai dengan peraturan perundang-undangan perpajakan. WP OP dalam negeri adalah orang pribadi yang bertempat tinggal atau berada di Indonesia lebih dari 183 hari (tidak harus berturut-turut) dalam jangka waktu 12 bulan atau orang pribadi yang dalam satu tahun pajak berada di Indonesia dan mempunyai niat untuk bertempat tinggal di Indonesia (Fikriningrum, 2012).

\section{Fungsi Pajak}

Berdasarkan Siti Resmi (2017:3) terdapat dua fungsi pajak, yaitu fungsi budgetair (sumber keuangan negara) dan fungsi regularend (pengatur).

1. Fungsi Budgetair (Sumber Keuangan Negara)

Pajak mempunyai fungsi budgetair, artinya pajak merupakan salah satu sumber penerimaan pemerintah untuk membiayai pengeluaran, baik rutin maupun pembangunan. Sebagai sumber keuangan negara, pemerintah berupaya memasukkan uang sebanyak-banyaknya untuk kas negara. Upaya tersebut ditempuh dengan cara ekstensifikasi dan intensifikasi Pajak Penghasilan (PPh), Pajak Pertambahan Nilai (PPN), Pajak Penjualan atas Barang Mewah (PPnBM), Pajak Bumi dan Bangunan (PPB), dan sebagainya.

2. Fungsi Regulerend (Pengatur)

Pajak mempunyai fungsi pengatur, artinya pajak sebagai alat untuk mengatur atau melaksanakan kebijakan pemerintah dalam bidang sosial dan ekonomi serta mencapai tujuan-tujuan tertentu di luar bidang keuangan. Berikut ini beberapa contoh penerapan pajak sebagai fungsi pengatur.

a. Pajak Penjualan atas Barang Mewah dikenakan pada saat terjadi transaksi jual beli barang tergolong mewah. Semakin mewah suatu barang, tarif pajaknya semakin tinggi sehingga barang tersebut harganya semakin mahal. Pengenaan pajak ini dimaksudkan agar rakyat tidak berlomba-lomba untuk mengkonsumsi barang mewah (mengurangi gaya hidup mewah).

b. Tarif pajak progresif dikenakan atas penghasilan, dimaksudkan agar pihak yang memperoleh penghasilan tinggi memberikan kontribusi (membayar pajak) yang tinggi pula sehingga terjadi pemerataan pendapatan.

c. Tarif pajak ekspor sebesar $0 \%$ dimaksudkan agar para pengusaha terdorong mengekspor hasil produksinya di pasar dunia sehingga memperbesar devisa negara.

d. Pajak penghasilan dikenakan atas penyerahan barang hasil industri tertentu, seperti industri semen, industri kertas, industri baja, dan lainnya, dimaksudkan agar terdapat penekanan produksi terhadap industri tersebut karena dapat mengganggu lingkungan atau polusi (membahayakan kesehatan)

e. Pengenaan pajak $1 \%$ bersifat Final untuk kegiatan usaha dan batasan peredaran tertentu, dimaksudkan untuk penyederhanaan penghitungan pajak

f. Permberlakuan Tax Holiday, dimaksudkan untuk menarik investor asing agar menanamkan modalnya di Indonesia

\section{Kemauan Membayar Pajak}

Menurut Fikriningrum (2012) kemauan merupakan dorongan dari dalam diri seseorang berdasarkan pertimbangan pemikiran dan perasaan yang menimbulkan suatu kegiatan untuk mencapai tujuan tertentu, sedangkan kemauan membayar 
merupakan suatu keadaan dimana seseorang rela untuk mengeluarkan dan mengorbankan uangnya untuk memperoleh barang atau jasa (Widaningrum 2007 dalam Widayati dan Nurlis, 2010). Pajak merupakan prestasi yang dipaksakan oleh negara dan terutang kepada Wajib Pajak, tanpa ada kontraprestasi dan semata-mata digunakan untuk membiayai pengeluaran umum (Violita, 2015).

Berdasarkan penjelasan di atas, kemauan membayar pajak diartikan sebagai suatu nilai atau tindakan moral yang secara sukarela dilakukan oleh Wajib Pajak dengan mengeluarkan uang sesuai dengan peraturan yang berlaku, dimana uang tersebut akan dipergunakan untuk keperluan umum negara dengan tidak mendapatkan imbalan secara langsung dari negara. Hal serupa diungkapkan oleh Rantung dan Adi (2009) bahwa kemauan membayar pajak dapat diartikan sebagai suatu nilai yang rela dikontribusikan oleh seseorang (yang ditetapkan dengan peraturan) yang digunakan untuk membiayai pengeluaran umum negara dengan tidak mendapat jasa timbal (kontraprestasi) secara langsung.

Kemauan membayar pajak yang dimaksudkan dalam penelitian ini adalah sebagai persiapan Wajib Pajak dalam melakukan pembayaran pajak serta faktor yang berpengaruh terhadap kemauan membayar pajak. Oleh karena itu penelitian ini akan mengkaji lebih jauh tentang faktor-faktor yang diduga memengaruhi kemauan Wajib Pajak Orang Pribadi untuk memenuhi kewajiban membayar pajak, yaitu kesadaran membayar pajak, kualitas pelayanan, sanksi pajak dan persepsi kemudahan penggunaan e-Billing.

\section{Kesadaran Membayar Pajak (the awareness of paying taxes}

Kesadaran merupakan unsur dalam diri manusia dalam memahami realita dan bagaimana cara bertindak atau menyikapi terhadap realita. Kesadaran yang dimiliki oleh manusia, yaitu kesadaran dalam diri, akan diri sesama, masa silam dan kemungkinan masa depannya (Widayati dan Nurlis, 2010).

Berdasarkan definisi di atas, kesadaran merupakan sikap atau perilaku manusia yang didasari unsur untuk mau melakukan suatu hal yang akan dilakukan dan apa yang seharusnya dilakukan. Perilaku yang berkaitan dengan pekerjaan atau kegiatan tentu sangat dipengaruhi oleh niat atau motivasi. Seseorang yang memiliki niat untuk melakukan sesuatu akan mencoba untuk menerapkan hal tersebut dengan baik (Salman dan Sarjono, 2013). Nugroho (2012), kesadaran membayar pajak mempunyai arti keadaaan dimana seseorang mengetahui, mengerti dan memahami tentang cara membayar pajak. Irianto (2005) dalam Rantung dan Adi (2009) menguraikan beberapa bentuk kesadaran membayar pajak yang mendorong Wajib Pajak untuk membayar pajak, antara lain:

a. Kesadaran bahwa pajak merupakan bentuk partisipasi dalam menunjang pembangunan negara dengan menyadari bahwa Wajib Pajak mau membayar pajak karena merasa tidak dirugikan dari pemungutan pajak yang dilakukan. Pajak disadari dan digunakan untuk pembangunan negara guna meningkatkan kesejahteraan warga negara.

b. Kesadaran bahwa penundaan pembayaran pajak dan pengurangan beban pajak berdampak pada kurangnya sumber daya finansial yang dapat mengakibatkan terhambatnya pembangunan negara.

c. Kesadaran bahwa pajak ditetapkan dengan undang-undang dan dapat dipaksakan. Wajib Pajak akan membayar pajak karena pembayaran pajak disadari memiliki landasan hukum yang kuat dan merupakan kewajiban mutlak setiap warga Negara

\section{Kualitas Pelayanan (the quality of service)}

Kualitas merupakan suatu kondisi dinamis yang berhubungan dengan produk, jasa manusia, proses dan lingkungan yang memenuhi atau melebihi harapan dari pihak 
yang menginginkannya (Hardiningsih dan Wati, 2011). Pelayanan merupakan suatu perilaku seseorang terhadap orang lain yang ditunjukkan dengan memberikan informasi, fasilitas, motivasi dan sarana tanpa adanya kepemilikan dan digunakan untuk memberikan rasa nyaman dan aman serta puas, sehingga orang tersebut merasa dihargai (Tahar dan Rachman, 2014). Pelayanan pada sektor perpajakan dapat diartikan sebagai pelayanan yang diberikan oleh DJP kepada Wajib Pajak untuk membantu Wajib Pajak dalam memenuhi kewajiban perpajakannya (Jotopurnomo dan Yenni, 2013).

Pelayanan yang dimaksud dalam penelitian ini adalah pelayanan yang dilakukan oleh fiskus (petugas pajak) kepada Wajib Pajak saat berada di KPP. Pelayanan ini dapat berupa keramahan dalam melayani, cepat dalam merespon, adil dan tegas agar Wajib Pajak merasa dihargai, sehingga Wajib Pajak taat dalam melaksanakan kewajiban perpajakannya. Hubungan Wajib Pajak dengan petugas pajak dapat dimodelkan sebagai kontrak implisit yang melibatkan ikatan emosional yang kuat dan loyalitas (Cevik dan Harun, 2013).

Menurut Bitner dkk., (2010) kualitas pelayanan yang baik harus memenuhi lima dimensi, yaitu:

a. Berwujud (tangible) adalah seluruh bentuk penampilan fisik dari pemberi pelayanan, meliputi fasilitas fisik, perlengkapan dan sarana komunikasi.

b. Perhatian (emphaty) adalah sikap kontrak petugas pajak maupun Kantor Pelayanan Pajak. Empati tersebut dapat berupa kemudahan dalam melakukan komunikasi yang baik, perhatian pribadi, perhatian dan memahami kebutuhan maupun kesulitan Wajib Pajak.

c. Ketanggapan (responsiveness) adalah kemampuan atau keinginan petugas pajak untuk membantu dan memberikan pelayanan yang dibutuhkan Wajib Pajak. Hal ini berkaitan dengan tanggung jawab dan keinginan untuk memberikan jasa yang prima serta membantu Wajib Pajak apabila menghadapi masalah yang berkaitan dengan perpajakan.

d. Keandalan (reliability) adalah kemampuan untuk memberikan pelayanan yang dijanjikan dengan tepat dan kemampuan dapat dipercaya, terutama dalam memberikan pelayanan secara tepat dengan cara yang sesuai dengan jadwal yang telah dijanjikan tanpa melakukan kesalahan.

e. Jaminan (assurance) adalah jaminan yang diberikan oleh Kantor Pelayanan Pajak kepada Wajib Pajak pada saat mempergunakan pelayanan. Jaminan tersebut mencakup pengetahuan, kemampuan, kesopanan dan kejujuran yang dimiliki para petugas pajak.

Menurut Susmita dan Supadmi (2016) kualitas pelayanan adalah seluruh pelayanan terbaik yang diberikan dengan tujuan untuk tetap menjaga kepuasan bagi Wajib Pajak di KPP dan dilakukan berdasarkan undang-undang perpajakan. Hal ini sejalan dengan pendapat Nugroho (2012) bahwa pelayanan yang baik adalah salah satu faktor yang penting dalam menciptakan kepuasan kepada pelanggan (Wajib Pajak). Suatu pelayanan dapat dikatakan baik, apabila usaha yang dijalankan sesuai dengan apa yang diharapkan oleh pihak yang diberi layanan. Artinya kualitas pelayanan merupakan pelayanan fiskus yang dapat memberikan kepuasan kepada Wajib Pajak dalam memenuhi kewajiban perpajakannya dan tetap dalam batas untuk memenuhi standar pelayanan yang dapat dipertangggungjawabkan serta harus dilakukan secara terus-menerus.

\section{Pajak Online}

Pajak online meruakan sistem elektronik yang disediakan oleh Dirjen Pajak atau pihak lain yang bekerja sama dengan Dirjen pajak. Tujuannya untuk mengadakan 
pelayanan dan transaksi elektronik terkait perpajakan. Keputusan terkait laporan pajak online ditulis dalam surat Edaran Dirjen Pajak Nomor SE-42/PJ/2017.

\section{E-Billing}

E-Billing merupakan wujud sistem adminitrasi odern agar lebih efisie ekonomis dengan ceapt yang dimaksudkan untuk meningkatkan kepatuhan dan kesadaran wajib pajak. E-Billing (15 digit angka) yang diterbitkan melalui sistem billing pajak. E-Billing mulai berlaku 1 Juli 2016, sebelum e-billing wajib pajak harus membuat kode billing wajib pajak harus membuat kode billing melalui cotomer servis atau teller bank, kring pajak 1500200, sms id billing, layanan billing di kpp atau KP2KP, internet banking maupun penyedia jasa aplikasi (ASP). Pembayaran e-billing melalui berbagai cara yaituteller bank, kantor pos, ATM, mini ATM di kpp atau KP2KP, dan internet banking.

Billing system adalah sistem yang menerbitkan kode billing untuk pembayaran atau penyetoran penerimaan negara secara elektronik tanpa perlu membuat Surat Setoran (SSP, SSBP, SSPB) manual yang digunakan e-billing Direktorat Jenderal Pajak. Modul Penerimaan Negara Generasi Pertama (MPN-G1) yang digunakan e-Billing Direktorat Jenderal Pajak dan mekanisme pembayaran pajak lainnya yang selama ini digunakan. Modul penerimaan Negara Generasi Kedua (MPNG2) adalah sistem penerimaan negara yang menggunakan surat setoran elektronik. Surat setoran elektronik adalah surat setoran yang berdasarkan pada sistem billing. (Direktorat Jenderal Pajak, 2017. http://www.pajak.go.id. e-biling)

Ada 3 (tiga) dasar hukum e-billing sistem adalah sebagai berikut:

1. PMK-242/ PMK.03/2014 Tentang Tata Cara Pembayaran Dan Penyetoran Pajak

2. PMK-32/ PMK.05/2014 Tentang Sistem Penerimaan Negara Secara Elektronik

3. Per-26/Pj/2014 Tentang Sistem Pembayaran Pajak Secara Elektronik. (Forum Pajak,2015) Ada beberapa manfaat dari penggunaan sistem e-billing adalah sebagai berikut:

a. Lebih Mudah

1) Tidak perlu lagi mengantri di loket teller untuk melakukan pembayaran. Sekarang telah dapat melakukan transaksi pembayaran pajak melalui Internet Banking Mandiri cukup dari meja kerja atau melalui mesin ATM Mandiri yang ditemui di sepanjang perjalanan.

2) Tidak perlu lagi membawa lembaran SSP ke Bank atau Kantor Pos Persepsi. Sekarang hanya cukup membawa catatan kecil berisi Kode Billing untuk melakukan transaksi pembayaran pajak untuk ditunjukkan ke teller atau dimasukkan sebagai kode pembayaran pajak di mesin ATM atau Internet Banking.

b. Lebih Cepat

1) Dapat melakukan transaksi pembayaran pajak hanya dalam hitungan menit dari mana pun berada

2) Jika memilih teller Bank atau Kantor Pos sebagai sarana pembayaran, sekarang tidak perlu lagi menunggu lama teller memasukkan data pembayaran pajak Anda, karena Kode Billing yang ditunjukkan akan memudahkan teller mendapatkan data pembayaran berdasarkan data yang telah wajib pajak input sebelumnya

3) Antrian di Bank atau Kantor Pos akan sangat cepat berkurang karena teller tidak perlu lagi memasukkan data pembayaran pajak.

c. Lebih Akurat

1) Sistem akan membimbing wajib pajak dalam pengisian SSP elektronik dengan tepat dan benar sesuai dengan transaksi perpajakan wajib pajak, sehingga kesalahan data pembayaran, seperti kode akun pajak dan kode jenis setoran, dapat dihindari. 
2) Kesalahan entry data yang biasa terjadi di tellerdapat terminimalisasi karena data yang akan muncul pada layar adalah 20 data yang telah wajib pajak input sendiri sesuai dengan transaksi perpajakan wajib pajak yang benar. (Direktorat Jenderal Pajak, 2017. http://www.pajak.go.id.e-biling)

\section{HASIL PENELITIAN DAN PEMBAHASAN}

\section{Tata Cara Pembayaran Pajak Melalui Kantor Pos}

Pada era Modul Penerimaan Negara Generasi 1 (MPN G1), wajib pajak harus membayar pajak secara manual menggunakan SSP / Surat Setoran Pajak. Saat ini, SSP Pajak / Surat Setoran Pajak sudah tidak lagi digunakan dan digantikan oleh SSE / Surat Setoran Elektronik. Hadirnya Modul Penerimaan Negara Generasi (MPN G2) yang memungkinkan wajib pajak membayar pajak secara online berkontribusi terhadap naiknya realisasi penerimaan pajak. Berikut ini penjelasan perbandingan MPN G1 dengan MPN G2 yang dapat penulis berikan:

1. Tata Cara Pembayaran Pajak Manual Melalui Kantor Pos Menggunakan Surat Setoran Pajak (SSP).

Dalam rangka mempercepat proses penatausahaan penerimaan setoran pajak, diperlukan adanya suatu sistem pelaporan yang dapat digunakan untuk mengetahui penerimaan negara yang berasal dari penerimaan pajak secara langsung dari PT. Pos Indonesia (Persero). Dengan adanya perkembangan teknologi informasi memungkinkan Direktorat Jenderal Anggaran dan Direktorat Jenderal Pajak mengetahui penerimaan negara khususnya penerimaan pajak dengan akurat secara real time melalui jaringan sistem informasi yang terhubung secara on-line dengan PT. Pos Indonesia (Persero).

PT. Pos Indonesia (Persero) adalah Badan Usaha Milik Negara yang mempunyai Unit pelaksana Teknis di daerah yaitu Sentral Giro/Sentral Giro Gabungan/Sentral Giro Gabungan Khusus dan Kantor Pos dan Giro. Surat Setoran Pajak (SSP) Standar adalah surat yang oleh Wajib Pajak/Penyetor digunakan atau berfungsi untuk melakukan pembayaran atau penyetoran pajak yang terutang ke kas negara melalui PT. Pos Indonesia (Persero) dan digunakan sebagai bukti/tanda pembayaran dengan bentuk, ukuran dan isi yang telah ditetapkan oleh Direktorat Jenderal Pajak. SSP Khusus adalah bukti/tanda pembayaran atau penyetoran pajak terutang ke kas negara yang dicetak oleh PT. Pos Indonesia (Persero) dengan menggunakan mesin transaksi dan atau alat lainnya, dan mempunyai fungsi yang sama dengan SSP Standar dalam administrasi perpajakan.

Pembayaran atau penyetoran pajak melalui PT. Pos Indonesia (Persero) dengan sistem pembayaran secara on line dilakukan sesuai dengan prosedur pengoperasian dengan menggunakan fasilitas pelayanan penyetoran pajak yang disediakan PT. Pos Indonesia (Persero) pada Kantor Pos Persepsi online. Bukti pembayaran atau penyetoran pajak melalui PT. Pos Indonesia (Persero) yang telah diolah dengan sistem pembayaran secara online dianggap sah sebagai bukti penyetoran/pembayaran pajak apabila SSP Khusus telah diberi NTP dan atau NTPP. Dalam hal pembayaran atau penyetoran Pajak Penghasilan Pasal 25 dilakukan melalui PT. Pos Indonesia (Persero) yang telah diolah dengan sistem pembayaran on line, SSP Pajak Penghasilan Pasal 25 tersebut dianggap telah dilaporkan ke Kantor Pelayanan Pajak (KPP) sesuai dengan tanggal yang tercantum pada SSP Khusus yang bersangkutan. Bukti pembayaran atau penyetoran pajak melalui PT. Pos Indonesia (Persero) yang telah diolah dengan sistem pembayaran secara on line tetap dilaporkan ke KPP sesuai ketentuan yang berlaku. 
2. Cara Mengisi Formulir SSP Pajak/Surat Setoran Pajak:

SSP Pajak atau formulir Surat Setoran Pajak merupakan lembaran yang berisi informasi berupa NPWP, nama wajib pajak, alamat wajib pajak, nomor objek pajak, alamat objek pajak, kode akun pajak dan kode jenis setoran. Selain itu terdapat juga uraian pembayaran, masa pajak, tahun pajak, nomor ketetapan dan jumlah pembayaran.

Perlahan tapi pasti, cara setor pajak manual pun ditinggalkan karena banyaknya kelemahan. Sejumlah kelemahan yang menonjol adalah buruknya kualitas data pembayaran, serta banyaknya pembatalan transaksi yang dilakukan perbankan.

Penyebab dibatalkannya transaksi biasanya karena kesalahan petugas teller maupun wajib pajak itu sendiri. Alasan lain diubahnya sistem pembayaran pajak adalah karena pembayaran pajak secara manual sudah tidak lagi sesuai dengan perkembangan teknologi informasi.

Berikut ini, cara mengisi Formulir Surat Setoran Pajak secara manual:

a. sikan NPWP atau Nomor Pokok Wajib Pajak

b. Isikan nama wajib pajak

c. Isikan alamat wajib pajak.

d. Isikan Nomor Objek Pajak, bila ada.

Nomor Objek Pajak Pajak Bumi dan Bangunan yang selanjutnya disingkat dengan NOP adalah nomor identitas objek pajak Pajak Bumi dan Bangunan (PBB) yang diberikan oleh DJP Pajak pada saat dilakukan pendaftaran dan/atau pendataan objek pajak PBB dan digunakan dalam administrasi perpajakan serta sebagai sarana wajib pajak dalam melaksanakan hak dan kewajiban perpajakannya.

e. Isikan alamat Objek Pajak Anda pada formulir Surat Setoran Pajak bila ada.

f. Isikan Kode Akun Pajak (KAP). Kode Akun Pajak adalah kode dari nama pajak yang akan Anda setorkan. Misalnya, Kode Akun Pajak untuk PPh Pasal 21 adalah KAP 411121.

g. Isikan Kode Jenis Setoran (KJS). Kode Jenis Setoran adalah kode jenissetoran pajak yang hendak Anda bayarkan. Misalnya Kode Jenis Setoranuntuk penyetoran SPT Masa adalah 300. Lihat daftar lengkap KAP dan KJS di sini.

h. Isikan uraian pembayaran berupa keterangan yang Anda perlu Anda tuliskan.

i. Berikan tanda silang $(\mathrm{X})$ pada masa pajak atau bulan yang pajaknya hendak Anda setorka

j. Isikan tahun dari pajak yang hendak bayarkan pada formulir Surat Setoran Pajak Anda.

k. Isikan nomor ketetapan, bila ada denda yang hendak harus dibayarkan, yaitu STP (Surat Tagihan Pajak), SKPKB (Surat Ketetapan Pajak Kurang Bayar) atau SKPKBT (Surat Ketetapan Pajak Kurang Bayar Tambahan).

I. Isikan jumlah pembayaran pajak dalam mata uang rupiah.

m. Isikan jumlah terbilangnya.

n. Terakhir, bubuhkan tanda tangan Anda beserta tanggal penyetoran pajak pada bagian bawah formulir Surat Setoran Pajak.

Langkah berikutnya setelah selesai mengisi formulir Surat Setoran Pajak, kita dipersilahkan melanjutkan ke tahapan pembayaran pajak secara manual, yang dilaksanakan dengan langkah-langkah seperti berikut ini:

a. Menyerahkan SSP pajak yang sudah dilengkapi kepada teller bank, maupun kantor pos persepsi beserta uang setoran sebesar nilai yang tertera dalam Surat Setoran Pajak. 
b. Menerima kembali SSP pajak lembar 1 dan 3 yang berisi NTPN dan NTB/NTP dan telah ditandatangani oleh pejabat bank atau kantor pos sebagai bukti setor.

c. Melaporkan bukti setor pada KPP

Lantaran banyaknya kelemahan, sejak 1 Juli 2016, pembayaran pajak menggunakan SSP pajak sudah tidak lagi berlaku. Sebagai gantinya, pemerintah meluncurkan MPN G2 yang menggantikan SSP pajak dengan Surat Setoran Elektronik (SSE) yang berdasarkan pada sistem billing. Sistem baru ini lebih disukai karena lebih memudahkan dan menurunkan risiko kesalahan yang sering ditemui pada MPN Generasi 1.

3. Tata Cara Pembayaran Pajak Seacara Elektornik Melalui Kantor Pos.

Peraturan Menteri Keuangan No. 32/PMK.05/2014 Tentang Sistem Penerimaan Negara Secara Elektronik dan Keputusan Dirjend Perbendaharaan No.121/PB/2014 Tanggal 21 April 2014 telah menunjuk PT Pos Indonesia (Persero) sebagai Pos Persepsi yang melaksanakan Sistem Penerimaan Negara Secara Elektronik karena berdasarkan hasil UAT (User Acceptance Test) telah dinyatakan lulus.

Kantor pos juga merupakan salah satu kanal yang ditunjuk oleh pemerintah untuk melaksanakan sistem penerimaan negara secara elektronikmelalui sistem modul penerimaan negara "billing" generasi kedua (MPNG2).

Dengan on-line nya Kantor Pos di seluruh Indonesia akan memberikan keleluasaan dan akses yang lebih mudah bagi wajib pajak diseluruh pelosok negeri, daerah kepulauan dan daerah urban, untuk melakukan setoran pajak disadari tentunya dengan effort yang cukup besar.

Di era MPN G2, wajib pajak yang ingin membayar pajak harus terlebih dahulu mengakses e-billing untuk mendapatkan ID Billing. Sistem e-billing sendiri merupakan pengganti SSP pajak. Sementara ID billing merupakan kode identifikasi yang diterbitkan sistem billing atas suatu jenis pembayaran yang akan dilakukan wajib pajak dalam rangka identifikasi penerbit kode billing.

Untuk memperoleh ID billing, wajib pajak bisa memperolehnya melalui situs DJP Online atau penyedia jasa aplikasi (Application Service Provider/ASP) resmi DJP seperti OnlinePajak. Namun, untuk bias mengakses situs dan aplikasi tersebut, wajib pajak harus melakukan registrasi terlebih dahulu.

Setelah mendapatkan ID billing, wajib pajak bisa melakukan pembayaran pajak secara manual melalui teller bank, kantor pos persepsi, ataupun menggunakan metode pembayaran online. Caranya, cukup dengan menginput ID billing tersebut pada metode pembayaran pajak yang Anda pilih.

Pelaksanaan Setoran Penerimaan Negara secara Elektronik dengan MPN G-2 dilaksanakan dengan sangat mudah dengan cara sbb:

1) Registrasi Untuk mendapatkan User Id:

a. Daftarkan diri anda sebagai wajib pajak pada situs Billing Sistem dengan alamat: http://sse.pajak.go.id.

b. Pendaftaran gratis dengan menggunakan No. NPWP hanya 1 kali saja

2) Mendapatkan Kode Billing untuk pembayaran Pajak

a. Masuk ke situs Billing Sistem dengan User Id hasil pendaftaran

b. Masukkan data pembayaran pajak yang akan dilakukan

c. Catat atau cetak kode billing 15 digit yang diterbitkan secara sistem; sehingga tidak perlu membawa SSP

3) Membayar Pajak di Kantor Pos

a. Tunjukkan Kode Billing kepada Petugas Loket Pos

b. Setorkan uang sesuai jumlah pajak yang dibayar

c. Terima dan simpan Resi Pembayaran Pajak sebagai Bukti Penerimaan Negara. 
Pelaksanaan Setoran Penerimaan Negara secara Elektronik dengan MPN G-2

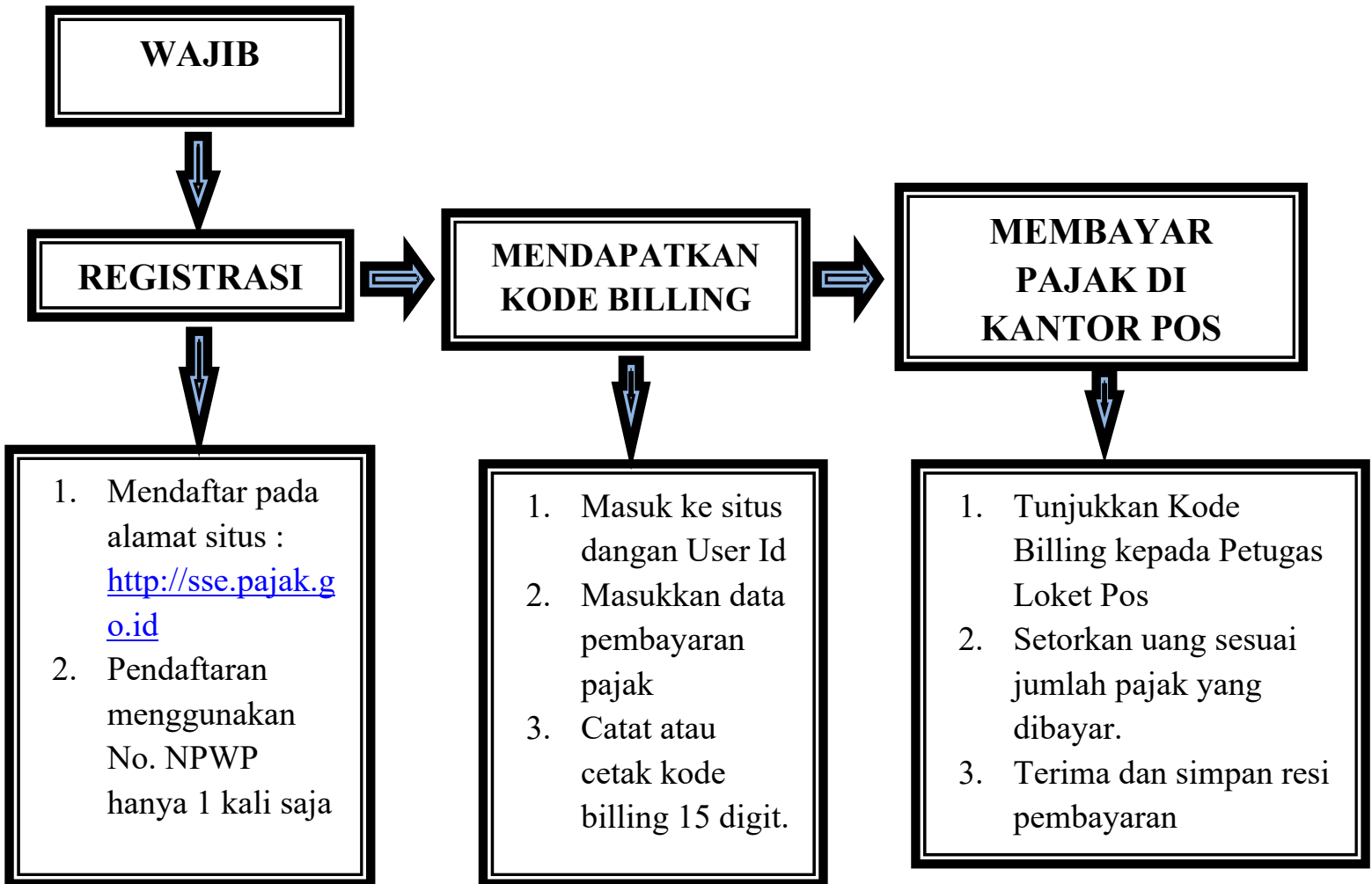

Flowchart 4.1 Pelaksanaan secara MPN G-2 Perbandingan Jumlah Masyarakat yang Membayar Pajak Setelah adanya Program Pembayaran Pajak Online dari Tahun 2019-2020

Tabel 2. Data transaksi pembayaran

\begin{tabular}{c|c|c|c}
\hline TAHUN & $\mathbf{2 0 1 7}$ & $\mathbf{2 0 1 8}$ & $\mathbf{2 1 0 9}$ \\
\hline Jumlah Transaksi & 394.416 & 503.618 & 515.632 \\
\hline $\begin{array}{c}\text { Jumlah Uang Yang } \\
\text { Disetor }\end{array}$ & Rp 179.365.332.012 & Rp 209.441.289.119 & Rp 235.522.789.479 \\
\hline
\end{tabular}

Sumber: Data pembayaran pajak online periode 2019-2020 PT Pos Indonesia (persero) Cabang Mataram

Tabel diatas menunjukkan perbandingan jumlah transaksi dan jumlah nominal yang dibayar oleh masyarakat wajib pajak keapada PT Pos Indonesia (persero) Cabang Mataram periode 2017-2019. Dimulai pada bulan Januari tahun 2017- Desember tahun 2019, dimana data yang diperoleh yaitu : jumlah transaksi yang terjadi di tahun 2017 adalah 394.416 dengan jumlah uang yang di setor sebesar Rp 179.365.332.012. Terjadi kenaikan pada tahun 2018 dengan jumlah transaksi 503.618 dan jumlah uang yang disetor sebesar Rp 209.441.289.119. Sedangkan transaksi ditahun 2019 adalah pencapaian tertinggi pada saat ini, dengan jumlah transaksi sebesar 515.632, dengan jumlah uang yang disetor sebesar Rp 235.522.789.479. 


\section{SIMPULAN}

Berdasarkan hasil pembahasan yang telah dijelaskan pada uraian pembahasan, maka penulis dapat menyimpulkan bahwa Pengaruh layanan pembayaran pajak online pada Pt. Pos Indonesia (persero) mataram terhadap peningkatan jumlah sadar pajak sesuai dengan peraturan menteri keuanngan republik Indonesia Nomor 32/PMK.05/2014 tentang sistem penerimaan negara secara elektronik telah berjalan dengan sangat baik, dimana Pt. Pos Indonesia memberi kemudahan dan kelancaran pelaksanaan pembayaran pajak online bagi wajib pajak dalam melaksanakan pembayaran pajak. Dalam melaksanakan pembayaran pajak di kantor pos dengan menunjukkan kode billing kepada petugas loket pos, menyerahkan data data wajib pajak yang lengkap, menyetorkan uang sesuai jumlah yang sudah ditentukan, kemudian wajib pajak menerima resi pembayaran pajak sebagai bukti penerimaan negara.

\section{DAFTAR PUSTAKA}

Anonim.2019. Pajak e-biling.Http://www.pajak.go.id e-biling. Diakses tanggal 21 Maret 202018.05 WITA.

Bahri Arifin, Syamsul dan Syafii, Indra.2019. Penerapan E-Filing, E-Billing dan Pemeriksaan Pajak Terhadap Kepatuhan Wajib Pajak Orang Pribadi diKpp Pratama Medan Polonia. Jurnal Akuntansi dan Bisnis: Jurnal Program studi Akuntansi. Vo.5, No.1:9-22

Hardiningsih, Pancawati.2011. Faktor-Faktor yang Mempengaruhi Kemauan Membayar Pajak. Jurnal Dinamika Keuangan dan Perbankan. Vol. 3, No. 1:126 - 142.

Irianto, Slamet Edi. 2005. Politik Perpajakan: Membangun Demokrasi Negara. Yogyakarta: UII Press.

Nurmantu, Safri. 2007. Pengantar Perpajakan. Jakarta: Granit

Resmi, Siti. 2016. perpajakan: Teoti dan Kasus. Edisi 10. Jakarta: Salemba Empat.

Suryadi.2006. Model Hubungan Kausal Kesadaran, Pelayanan, Kepatuhan Wajib Pajak dan Pengaruhnya Terhadap Kinerja Penerimaan Pajak.Jurnal Keuangan Publik. Vol 4,1: 105-121.

Tahar, Rachman, 2014. Pengaruh Faktor Internal dan Faktor Eksternal Terhadap Kepatuhan Wajib Pajak. Jurnal Akuntansi dan Investasi.Vol. 15, No 1, Januari 2014, Hal: 57-67.

Widayati dan Nurlis. 2010. Faktor-Faktor Yang Mempengaruhi Untuk Membayar Pajak Wajib Pajak Orang Pribadi Yang Melakukan Pekerjaan Bebas Studi Kasus Pada KPP Pratama Gambir Tig". Purwokerto: Proceeding Simposium Nasional Akuntansi XII. 